\section{EL ROL DE LAS EMOCIONES Y LOS AFECTOS EN LA PRODUCCIÓN DEL HÁBITAT Y EL TERRITORIO'}

Luis Campos Medina ${ }^{2}$, Rebeca Silva Roquefort ${ }^{3}$ y Mariela Gaete Reyes ${ }^{4}$

En la convocatoria a este número especial decíamos que los estudios territoriales y urbanos latinoamericanos no han recogido con suficiente claridad y fuerza la pregunta por el papel que juegan las emociones y los afectos en los distintos fenómenos que estudian. En contraste con lo que pasa en dominios cercanos -como la geografía humana (Davidson, Bondy y Smith, 2007; Lindón, 2009

1 Luis Campos agradece CONICYT Fondecyt de Iniciación 11140356.

2 Chile. Instituto de la Vivienda Facultad de Arquitectura y Urbanismo Universidad de Chile. Correo electrónico: luiscampos@ uchilefau.cl.

3 Chile. Instituto de la Vivienda Facultad de Arquitectura y Urbanismo Universidad de Chile. Correo electrónico: bekysilva@ uchilefau.cl.

4 Chile. Instituto de la Vivienda Facultad de Arquitectura y Urbanismo Universidad de Chile. Correo electrónico: m.gaetereyes@uchilefau.cl

\section{THE ROLE OF EMOTIONS AND AFFECTS IN THE PRODUCTION OF HABITAT AND TERRITORY ${ }^{1}$}

Luis Campos Medina ${ }^{2}$, Rebeca Silva Roquefort ${ }^{3}$ y Mariela Gaete Reyes ${ }^{4}$

In the call for submissions for this special issue, we said that Latin American territorial and urban studies have not investigated with sufficient clarity and strength the question of the role played by emotions and affects in the different phenomena that they study. As opposed to related fields, -like human geography (Davidson, Bondi, \& Smith, 2007;

1 Luis Campos acknowledges CONICYT Initiation Fondecyt 11140356.

2 Chile. Housing Institute, Faculty of Architecture and Urbanism, University of Chile.Email: luiscampos@uchilefau.cl.

3 Chile. Housing Institute, Faculty of Architecture and Urbanism, University of Chile. Email: bekysilva@uchilefau.cl.

4 Chile. Housing Institute, Faculty of Architecture and Urbanism, University of Chile. Email: m.gaete-reyes@uchilefau.cl. 
y 2012; Guinard y Tratnjek, 2016; Smith et al., 2009)-, aquí dicha interrogante es más bien incipiente, hasta rudimentaria. Nuestra convocatoria tenía, en consecuencia, el propósito de poner a prueba esa doble condición -incipiente y rudimentaria- para así obtener una estimación del interés que generaba la temática, conocer los ámbitos en los que se desplegaba la pregunta por las emociones y los afectos, los marcos teóricos convocados y los enfoques metodológicos en uso (Aguilar y Soto, 2013; Albornoz, 2016; Deluermoz et al., 2013; Gregg y Seigtworth, 2010).

El resultado fue auspicioso, pues recibimos más de cuarenta artículos, escritos por autores/as de distintos países de habla hispana, que abordaban diversos temas y que se interrogaban sobre la incidencia que le cabía a los afectos y las emociones en la forma y textura que asumía cada fenómeno estudiado. Un panorama alentador o, dicho en sintonía con la teoría de los afectos de Spinoza (Spinoza, 1980; Vigotsky, 2010), un panorama que nos impulsa a explorar con mayor detalle el modo en que nos hemos preguntado por el rol que juegan las emociones y los afectos en la producción del hábitat y el territorio. Veamos con más detalle ese panorama.

El conjunto de artículos presentados en este número especial de Revista INVI nos muestra que la pregunta por los afectos y las emociones posee una vasta extensión en los estudios del hábitat y el
Lindón, 2009 \& 2012; Guinard \& Tratnjek, 2016; Smith et al., 2009) -, in this field the question is more incipient, even rudimentary. Our call for submissions was therefore intended to put this double condition-incipient and rudimentary - to the test. We wanted to gauge the interest generated by the topic and discover the fields where this question of emotion and affects was already unfolding, the theoretical frameworks invoked, and the methodological approaches in use (Aguilar \& Soto, 2013; Albornoz, 2016; Deluermoz et al., 2013; Gregg E Seigtworth, 2010).

The outcome was auspicious: more than forty articles, written by authors from a variety of Spanish-speaking countries, and which addressed diverse topics and questioned the influence of affects and emotions on the form and texture taken on by each phenomenon under study. This is a promising picture, or, in line with Spinoza's theory of affects (Spinoza, 1980; Vigotsky, 2010), a picture that prompts us to explore in greater depth the way in which we have questioned the role played by emotions and affects in the production of habitat and territory. Let's look at this picture in more detail.

The collection of articles in this special issue of Revista INVI shows us that the question of affects and emotions has a wide range within habitat and territory studies. It is put into play in the 
territorio, ya que es puesta en juego en el análisis de variados fenómenos: en el estudio del apego al lugar y del significado del espacio habitado, pero también en las luchas patrimoniales, el estigma territorial, la informalidad, las migraciones urbanorurales y el gobierno de los otros.

Además, el corpus de siete artículos nos indica que el uso de la perspectiva de los afectos y las emociones permite construir objetos de investigación variados. En efecto, no se trata sólo de diversidad temática, sino que de modos de problematizar que buscan "deconstruir" o "desempaquetar" procesos que se dan por sentados. Aquí la referencia al apego al lugar resulta ejemplar, porque apego, arraigo y pertenencia son piezas clave en el "juego de lenguaje" que conforman los estudios del hábitat y el territorio. Sin embargo, a pesar de ser nociones habituales para arquitectos/as, geógrafos/as, urbanistas, etc., no siempre son interrogadas para saber qué quieren decir con exactitud. El enfoque de los afectos consigue desmenuzar y hacer visible el papel que cumplen distintos elementos en la producción del apego, el arraigo y la pertenencia. Es el caso explícito del artículo de Berroeta, Pinto de Carvalho, Di Masso y Ossul. Pero también del artículo de Aubán y, de formas diferentes, de los textos de Colin, Hueliñir y Zunino, y Skewes, Trujillo y Guerra, todos ellos contenidos en el presente número. analysis of diverse phenomena: in the study of place attachment and the meaning of inhabited space, but also in struggles over heritage, territorial stigmatization, informality, urbanrural migrations and the government of others.

Additionally, the seven-article corpus shows that the use of the affect and emotion perspective enables the construction of different objects of research. Indeed, the question is not just about thematic diversity, but also about ways of problematizing that seek to "deconstruct" or "unpack" processes that are taken for granted. The reference to place attachment is a good example: attachment, rooting, and belonging are key pieces in the "language game" of habitat and territory studies. However, despite being common notions for architects, geographers, urban planners, etc., they are not always questioned to unearth their precise meaning. The affects approach manages to scrutinize and unveil the role that different elements play in the production of attachment, rooting and belonging. This is explicitly the case in the article by Berroeta, Pinto de Carvalho, Di Masso and Ossul and the article by Aubán. And in different ways, this is the case in the texts by Colin, Hueliñir and Zunino, and Skewes, Trujillo and Guerra. All of these texts are found in this issue. 
En ese sentido, en el ámbito de los estudios del hábitat y el territorio, el enfoque de los afectos actúa con vocación microscópica, pues busca ofrecernos la textura sutil de ciertos procesos, iluminando sus aspectos subjetivos, socio-culturales y sociomateriales. En cierto modo, nos revela aquellos aspectos que dan forma a la cara oculta de los procesos habitualmente considerados en los estudios urbanos. Pero esta situación nos sugiere que existe una limitación: se trata de un enfoque que ofrece rendimientos principalmente en una escala -la micro-, sin conseguir remontarse a otras, como la meso o la macro. A diferencia de lo que ocurre en otros dominios de investigación, donde se promueve un tratamiento afectivo de la macro-escala -como sugiere la propuesta del "estructuralismo de las pasiones" de Lordon (2013) para el ámbito de la economía o la política-, acá el enfoque sería de utilidad a nivel de lo micro.

La concentración en la escala micro no tiene que ver, sin embargo, con el privilegio de ciertos marcos conceptuales por sobre otros. En este punto los artículos que forman el número especial muestran una variedad y eclecticismo importante. No se constata, en consecuencia, algún tipo de afinidad o recurrencia entre la pregunta por los afectos y las teorías que son convocadas, sino más bien un diálogo en función de la pertinencia interpretativa de los conceptos y las teorías. A esto contribuye, por cierto, la diversidad disciplinar de los/as
In the field of habitat and territory studies, the affects approach works with a microscopic focus: it seeks to offer us the subtle texture of certain processes, illuminating their subjective, sociocultural and socio-material aspects. In a way, it reveals the aspects that make up the hidden face of the processes typically examined by urban studies. But this suggests a limitation: this approach yields results on one scale only -the micro- without being able to rise to the meso or the macro. As opposed to other fields of research, which promote an affective treatment of the macro-scale, as suggested by Lordon's (2013) proposed "structuralism of passions" in the field of economics or politics, here the approach is useful on the micro-level.

Concentration on the micro-scale, however, does not mean certain conceptual frameworks are privileged over others. In fact, in this regard, the articles in this special issue show significant eclecticism and variety. There is not affinity or recurrence between the question of affects and the theories that are discussed, but rather there is a dialogue based on the interpretive relevance of the concepts and theories. This is of course supported by the disciplinary diversity of the authors in the issue, and this is indicative of another element: the transversality of the affects approach across the disciplines that feed into territory and habitat studies. This issue contains 
autores/as del número, lo que se vuelve indicativo de otro elemento: la transversalidad del enfoque de los afectos entre las disciplinas que alimentan los estudios territoriales y del hábitat. Así, geógrafos/ as, arquitectos/as, antropólogos/as, sociólogos/as, entre otros, están presentes en el número.

Finalmente, el conjunto de artículos seleccionados nos muestra una variedad de enfoques metodológicos posibles de utilizar en el estudio de los afectos y las emociones. Enfoques que incluyen la etnografía, las entrevistas, los grupos focales, la aplicación de encuestas y el análisis estadístico. Incluso el análisis de documentos en clave genealógica. La diversidad de opciones se vuelve, así, un nuevo aliciente para la investigación sobre la temática, en la medida que nos muestra que ella no se encuentra restringida a cierto tipo de abordajes - por ejemplo, los etnográficos desconfiados de la representación y el discurso-, sino que más bien requiere de la articulación creativa de técnicas de producción de información y de análisis de datos. En ese sentido, la diversidad de opciones metodológicas funciona como un llamado al despliegue de la "imaginación investigativa", parafraseando a Charles Wright Mills (Mills, 1959; Back y Puwar, 2012).

Tenemos en frente, en consecuencia, un conjunto de artículos que da cuenta de: i) la versatilidad del enfoque de los afectos, en la medida que se aplica a un espectro de fenómenos variado; ii) la relevancia teórica de dicho enfoque, en cuanto permite ver geographers, anthropologists, sociologists, and more.

Finally, the articles selected show the variety of methodological approaches that can be used in the study of affects and emotions. These include ethnography, interviews, focus groups, surveys, statistical analysis, and even the analysis of genealogical documents. The diversity of opinions thus becomes a new incentive for research on this topic, insofar as it shows that the subject is not restricted to certain types of approaches -such as that, for example, of ethnographers distrustful of representation and discourse-, but rather that it requires the creative articulation of information production and data analysis techniques. In this regard, the diversity of methodological options acts as a call for "investigative imagination," paraphrasing Charles Wright Mills (Mills, 1959; Back \& Puwar, 2012).

Thus we have before us a set of articles that shows: i) the versatility of the affects approach, as it applies to a spectrum of varied phenomena; ii) the theoretical relevance of this approach, insofar as it allows the phenomena to be viewed from different angles; iii) its micro-level relevance, revealing less conventional dimensions; iv) its conceptual pluralism, given its dialogue with diverse traditions of thought and disciplines and; v) finally, its methodological adaptability. Below, we will look at the salient features of the 
los fenómenos desde ángulos diferentes; iii) su pertinencia microscópica y reveladora de dimensiones menos convencionales; iv) su pluralismo conceptual, puesto que dialoga con diversas tradiciones de pensamiento y disciplinas y; v) finalmente, su adaptabilidad metodológica. Veremos a continuación las características destacadas de los artículos incluidos en este número especial en algunas de estas cinco dimensiones.

El primer artículo es "Traer el bosque a sus domicilios. Transformaciones de los modos de significar el espacio habitado", de los autores Skewes, Trujillo y Guerra, en el que se nos muestra la manera en que los cambios en las actividades productivas inciden en la forma y significado del hábitat y el territorio, pero con una particular sensibilidad puesta en el rol jugado por materialidades y agencias no humanas. En este sentido, el texto funciona como un recordatorio de que nuestras escalas afectivas están en constante transformación y no son ajenas a las modificaciones en los modos de producción predominantes. Más aún, los autores nos indican que la proyección temporal y la sustentabilidad de esos cambios dependen de la capacidad de los propios habitantes para reorganizar sus formas de vinculación emocional con el medio y producir hábitat. Visto así, este último emerge como una entidad de geometría variable y en variación; una entidad poblada por más actores de los que usualmente reciben la etiqueta de habitantes, ya que abejas y matorrales también participan de la articles included in this special issue in some of these dimensions.

The first article is "Bring the forest to your homes. Transformations of ways of signifying inhabited space," by the authors Skewes, Trujillo and Guerra. It shows us how changes in productive activities affect the form and meaning of habitat and territory, but with a particular awareness of the role played by materialities and non-human agencies. In this sense, the text works as a reminder that our affective scales are in constant transformation and are not unrelated to modifications in the predominant modes of production. Moreover, the authors state that the future and sustainability of these changes depend on the capacity of the inhabitants to reorganize the forms of emotional attachment to the environment and produce habitat. Seen this way, habitat emerges as an entity of variable geometry and in variation; an entity populated by more actors than usually receive the label of inhabitants, since bees and shrubs also participate in the production of home. Thus the article acts as an invitation to renew the ontologies and epistemes that govern -almost always surreptitiously - the production of our objects of research in the field of territorial and habitat studies.

"Dignity in the margins. Affective approaches to the informal city," the article by Mónica Aubán, 
producción del hogar. El artículo funciona, entonces, como una invitación a renovar las ontologías y epistemes que gobiernan -casi siempre de modo subrepticio- la producción de nuestros objetos de investigación en el dominio de los estudios territoriales y del hábitat.

"La dignidad en los márgenes. Aproximaciones afectivas a la ciudad informal", el artículo de Mónica Aubán, es fuertemente persuasivo. La autora comienza dando cuenta -con precisión y sin estridencias- de la teoría del afecto en el linaje de Spinoza, Deleuze y Braidotti, para mostrarnos, a continuación, la pertinencia que dicha teoría tiene en el abordaje de la práctica arquitectónica contemporánea, en la medida que hace visibles aspectos propios de la subjetividad de los habitantes de territorios relegados. De acuerdo a Aubán, en el trabajo con expresiones informales del hábitat, la arquitectura ha conseguido importantes avances, entre los que destaca una noción ampliada de territorialidad -que permite integrar a más actores en la producción del hábitat-, así como también considerar cuestiones tales como los sentimientos de pertenencia, la identificación con el lugar y las reivindicaciones por la dignidad de los habitantes. Atender a estos elementos, claramente vinculados al plano afectivo, no sólo resulta adecuado, sino que, de intensificarse, reportaría importantes beneficios a la práctica arquitectónica y permitiría revertir la imagen negativa que ha predominado en el tratamiento de la ciudad informal. is strongly persuasive. The author begins by explaining, precisely and without stridency, the affect theory in the lineage of Spinoza, Deleuze and Braidotti, to then show the relevance that this theory has in the approach to contemporary architectural practice, insofar as it unveils aspects specific to the subjectivity of the inhabitants of neglected territories. According to Aubán, architecture has made significant advances in working with informal expressions of habitat. These include a broadened notion of territoriality, which enables the integration of more actors in the production of habitat, as well as a consideration of questions such as feelings of belonging, identification with place and reclaiming of the dignity of the inhabitants. Addressing these elements, which are clearly linked to the affective plane, is not only appropriate, but also, if intensified, would bring important benefits to architectural practice and would enable a reversal of the negative image that has predominated in the treatment of the informal city.

In the third article, "Nostalgia in urban production: The defense of neighborhoods in Santiago, Chile," the argumentative procedure Clément Colin deploys is clear and consistent: nostalgia is an emotion, a discourse and a practice that participates in the production of the urban environment. It is not a mental state, but rather a socio-cultural construction that is 
En el tercer artículo, "La nostalgia en la producción urbana: La defensa de barrios en Santiago de Chile", el procedimiento argumentativo desplegado por Clément Colin es claro y consistente: la nostalgia es una emoción, un discurso y una práctica que participa de la producción del entorno urbano. No se trata de un estado mental, sino que de una construcción socio-cultural que es utilizada como herramienta de apropiación simbólica del espacio y que permite proteger las dimensiones materiales del barrio. El artículo busca mostrarnos cómo es vivido el proceso de transformación neoliberal de la ciudad actual por parte de los habitantes, particularmente desde el punto de vista de aquellos que lo resienten y lo resisten. Al mostrarnos el papel que juega la nostalgia como motor de esa resistencia, Colin nos sugiere que las emociones no son fenómenos reflejos o reactivos, sino que tienen el poder de catalizar y canalizar la acción productiva, esto es defender el espacio que permite pensarnos, detener el avance inmobiliario, pero también constituir una identidad colectiva.

En su texto "Apego al lugar: una aproximación psicoambiental a la vinculación afectiva con el entorno en procesos de reconstrucción del hábitat residencial", los autores Berroeta, Pinto de Carvalho, Di Masso y Ossul nos ofrecen un mapeo preciso del modo en que se ha conceptualizado la noción de apego al lugar en la psicología ambiental. La propuesta identifica tres perspectivas teóricas que ponen el acento específico en: la afinidad used as a tool of symbolic appropriation of space and which enables the protection of the material dimensions of the neighborhood. The article aims to show us how the city's current process of neoliberal transformation is experienced by its inhabitants, particularly from the point of view of those who resent and resist it. By showing us the role that nostalgia plays as the engine of this resistance, Colin suggests that emotions are not reflexive or reactive phenomena but rather have the power to catalyze and channel productive action: to defend the space that allows us to think about ourselves, stop the advance of real estate, but also constitute a collective identity.

In their text "Place attachment: a psychoenvironmental approach to affective attachment to the environment in residential habitat reconstruction processes" the authors Berroeta, Pinto de Carvalho, Di Masso and Ossul precisely map how the notion of place attachment has been conceptualized in environmental psychology. The proposal identifies three theoretical perspectives that place a specific emphasis on, first, individual emotional affinity for places, second, the recognition of the production of social meanings from which the affective attachments to place develop, and third, the exploration of the material practices through which affect for place is created and experienced. The cartography they offer is extremely valuable, not only to account for the forms and boundaries of these conceptual 
emocional individual hacia los lugares, la primera; el reconocimiento de la producción de significados sociales desde los que se elaboran los vínculos afectivos con el lugar, la segunda; y la exploración de las prácticas materiales a través de las cuales el afecto hacia el lugar es creado y vivido, la tercera. La cartografía ofrecida es extremadamente valiosa, no sólo por dar cuenta de las formas y límites de estos continentes conceptuales, sino que también porque sugiere un relato de profundización progresiva que va de lo individual a lo grupal, de lo intangible a lo material, de lo representacional a lo práctico. Además de eso, la propuesta consigue ser más auspiciosa en virtud del diálogo establecido con información empírica generada en tres contextos locales afectados por desastres socio-naturales, mediante técnicas variadas, entre las que se cuenta, para sorpresa de algunos, el análisis estadístico.

El quinto texto del número especial, "Movilidad, utopías y lugares híbridos en Los Andes del sur de Chile", de los autores Huiliñir-Curío y Zunino, comienza recordándonos que "la palabra emoción, del latín emotio, deriva del verbo emovere, que significa 'retirar, desplazar de un sitio, mover' y nos propone un análisis de la migración utópica que constituye, en sí mismo, una suerte de ejemplificación "escalada" de la palabra emoción, ya no a nivel del movimiento del cuerpo como resultado de un elemento que lo afecta, sino que del continents, but also because it suggests a narrative of progressive deepening going from the individual to the group, from the intangible to the material, and from the representational to the practical. In addition, the proposal becomes even more auspicious by virtue of the dialogue established with empirical information from three local contexts affected by socio-natural disasters. This information was generated by means of varied techniques, including, to the surprise of some, statistical analysis.

The fifth text of this special issue, "Mobility, utopias and hybrid places in the Southern Chilean Andes," by the authors Huiliñir-Curío and Zunino, begins by reminding us that "the word emotion, from the Latin emotio, comes from the verb emovere, which means 'to withdraw, to relocate from a place, to move." It then analyzes the utopian migration that constitutes in itself a sort of "scaled" exemplification of the word emotion: no longer at the level of movement of the body as a result of an element that affects it, but rather at the level of the displacement over a distance in space as a product of affects that are ascribed to, and are found crystallized within, a place. According to the authors, the cases analyzed, which are located in Southern Chile, offer a counterpoint to the homogenizing tendency of the modern rational project. 
desplazamiento kilométrico en el espacio como producto de los afectos que se le asignan a, y que se encuentran cristalizados en, un lugar. Situados en el sur de Chile, los casos analizados ofrecen, a juicio de los autores, un contrapunto a la tendencia homogeneizadora del proyecto racional moderno.

La propuesta de las autoras Ginga y Brizuela, "Iniciativas escenográficas en Rosario: lo cool como tecnología de gobierno de subjetividades urbanas", se inicia con el uso de la metáfora de la escenografía para sugerir que un conjunto de iniciativas público-privadas implementadas en la ciudad de Rosario, Argentina, tienen como propósito mostrar una versión parcial y restringida de la ciudad; una versión que resalta ciertos atributos ligados a lo cool, pero que tiene poco que ver con la dinámica propia de la ciudad y la experiencia de vida de sus habitantes. No obstante, esa versión parcial, "escenográfica", busca convertirse en un dispositivo orientador de la conducta de los habitantes, es decir, en una tecnología de gobierno de la subjetividad. Al mostrarnos la mecánica de esta operación, las autoras resaltan la importancia que tiene el deseo como impulsor de la actividad humana y como herramienta de dinamización del capitalismo actual, particularmente en su versión de goce.

Finalmente, el texto de Alfredo Santillán, "El sentir frente a la estigmatización territorial", aborda los sentimientos generados por la estigmatización territorial en la ciudad de Quito, destacando la
Ginga's and Brizuela's submission, "Scenographic initiatives in Rosario: cool as a technology for governing urban subjectivities," begins using the metaphor of scenography to suggest that a set of public-private initiatives implemented in the city of Rosario, Argentina, aim to show a partial and restricted version of the city. This version highlights certain "cool" attributes but has little to do with the city's dynamics and its inhabitants' life experience. However, this partial, "scenographic" version aims to become a device that guides the behavior of the inhabitants, that is, a technology to govern subjectivity. By showing us the mechanics behind this operation, the authors emphasize the importance of desire as an impeller of human activity and as a tool of revitalization of current capitalism, particularly in its version of enjoyment.

Finally, Alfredo Santillán's text "Feelings in the face of territorial stigmatization" addresses the feelings generated by territorial stigmatization in the city of Quito, highlighting the importance of the imaginary dimension in that process. The author shows us how the emotions of malaise and anger in the face of humiliation are reoriented toward demythification practices that openly dispute the content of injurious prejudices towards the "south" of the city, reclaiming the positive attributes of the people living in this urban sector. The analytical procedure used 
relevancia de la dimensión imaginaria en ese proceso. El autor nos muestra cómo las emociones de malestar e ira frente a la humillación son reorientadas hacia prácticas de desmitificación que disputan abiertamente el contenido de los prejuicios injuriosos sobre el "sur" de la ciudad, reivindicando atributos positivos de la gente que habita en este sector de la urbe. El procedimiento de análisis utilizado resulta revelador del potencial heurístico que posee un trabajo intensivo de un corpus acotado: el autor se toma en serio el lenguaje de los habitantes disectando sus distintas capas de significación y mostrando su pertinencia en el abordaje de las emociones y los afectos.

Como queda en evidencia, el conjunto de siete artículos que compone este número especial constituye una muestra variopinta de las distintas aproximaciones y usos que se han hecho de la perspectiva de los afectos y emociones. Además de proponer lecturas novedosas para las temáticas que trabajan, los textos instalan una serie de preguntas encaminadas a profundizar en los temas abordados. En este sentido, los siete artículos nos insinúan la necesidad de continuar el esfuerzo analítico realizado en cada uno de ellos. Todo lo anterior vuelve pertinente la pregunta por las implicancias de escribir sobre las emociones.

Efectivamente, escribir sobre las emociones es un intento de hacer visible teóricamente -si se nos permite el pleonasmo- un componente de la reveals the heuristic potential of an intensive work with a limited corpus: the author takes the language of the inhabitants seriously, dissecting the different layers of meaning and showing their relevance in the emotions and affects approach.

As evidenced, the seven articles that make up this special issue constitute a multicolored sample of the different approaches and uses made of the affect and emotion perspective. Apart from proposing novel readings of their respective subjects, these texts put forth a series of questions aimed at promoting deeper investigation of the issues they cover. The seven articles all imply the need to continue with the analytical efforts each of them has made. All of the above highlights the relevance of the question of the implications of writing about emotion.

Indeed, writing about emotions is an attempt to make theoretically visible -if we may be permitted the pleonasm-a component of habitat production and territory that seems to have been taken for granted. Writing about emotions is, in a sense, a way of giving a name to the traction that unites and revitalizes things, places and people (Ahmed, 2004). It is a way of enunciating absences, those that take the form of memories, past experiences, loved ones that have gone... these pasts that are present, these absences that populate our daily life, but rarely give us the time to name (Stewart, 2007). 
producción del hábitat y el territorio que por evidente pareciera darse por descontado. Escribir sobre las emociones es, en cierta forma, una manera de ponerle nombre a esa tracción que une y dinamiza cosas, lugares y personas (Ahmed, 2004). Una manera de enunciar las ausencias, esas que toman la forma de recuerdos, experiencias pasadas, seres queridos que se fueron... pasados que están presentes, ausencias que pueblan nuestro cotidiano, pero que raramente nos damos el tiempo de nombrar (Stewart, 2007).

Escribir sobre las emociones es, por otro lado, un gesto que reconoce que la forma en que está tejido nuestro mundo es más fina y enmarañada, y al mismo tiempo y por paradójico que suene, más volátil y más densa que lo que nos dejan ver nuestros utensilios conceptuales habituales. En ese sentido es una escritura que convoca a renovar paradigmas, a imaginar posibilidades (Knudsen y Stage, 2015).

Esperamos que el paisaje que esbozan los siete artículos de este número especial permita que los/ as lectores/as de Revista INVI no sólo se hagan una idea de la magnitud que tiene actualmente el estudio del rol que juegan las emociones y los afectos en la producción del hábitat y el territorio, sino que se convierta en un impulso que potencie las búsquedas, un llamado a aguzar el oído (Back, 2007), a afinar la mirada y, así, refrescar los estudios urbanos, territoriales y del hábitat.
Writing about emotions is, moreover, a gesture that recognizes that the way our world is woven is finer and more tangled, and at the same time, and as paradoxical as it sounds, more volatile and denser than what our usual conceptual tools allow us to see. In this sense, it is a form of writing that calls for the renewal of paradigms and the imagining of possibilities (Knudsen $\mathcal{E}$ Stage, 2015).

We hope that the landscape sketched out in this issue's seven articles will allow Revista INVI readers to not only get an idea of the magnitude of current research on the role played by emotions and affects in the production of habitat and territory, but will also serve as a catalyst to inspire research, and as a call to sharpen our ears (Back, 2007), to refine our gaze and thus to refresh urban, territorial and habitat studies. 


\section{Referencias bibliográficas}

Aguilar, M.A., y Soto, P. (2013). Cuerpos, espacios y emociones: aproximaciones desde las ciencias sociales. México: Miguel Ángel Porrúa.

Ahmed, S. (2004). The cultural politics of emotion. Edinburgh: Edinburgh University Press.

Albornoz, M.E. (2016). La historia de las emociones. En Albornoz, M.E. (Dir.), Sentimientos y justicia. Santiago: Acto Editores.

Back, L. (2007). The art of listening. Oxford: Berg.

Back, L., y Puwar, N. (Eds.). (2012). Live methods. London: Blackwell.

Davidson, J., Bondi, L., y Smith, M. (2007). Emotional geographies. London: Ashgate.

Deluermoz, 0., Fureix, E., Mazurel, H., y Oualdi, M. (2013). Écrire l'histoire des émotions: de l'objet à la catégorie d'analyse. Revue d'histoire du XIXe siècle, (47), 155-189. https://doi.org/10.4000/ rh19.4573.

Guinard, P., y Tratnjek, B. (2016). Géographies, géographes et émotions. Retour sur une amnésie... passagère? Carnets de Géographes, (9), 1-16.

Gregg, M., y Seigtworth, G. (2010). The affect theory reader. Durham: Duke University Press.

Knudsen, B.T., y Stage, C. (2015). Affective methodologies. Developing cultural research strategies for the study of affect. London: Palgrave Macmillan UK.
Lindón, A. (2009). La construcción socioespacial de la ciudad: el sujeto cuerpo y el sujeto sentimiento. Revista Latinoamericana de Estudios sobre Cuerpo, Emociones y Sociedad, (1), 6-20.

Lindón, A. (2012). Corporalidades, emociones y espacialidades: hacia un renovado betweenness. RBSE - Revista Brasileira de Sociologia da Emoção, 11(33), 698-723.

Lordon, F. (2013). La société des affects. Pour un structuralisme des passions. Paris: Éditions du Seuil.

Mills, C.W. (1959). The sociological imagination. Oxford: Oxford University Press.

Smith, M., Davidson, J., Cameron, L., y Bondi, L. (2009). Emotion, place and culture. London: Routledge.

Spinoza, B. (1980). Ética demostrada según el orden geométrico. Madrid: Editora Nacional.

Stewart, K. (2007). Ordinary affects. Durham: Duke University Press.

Vigotsky, L. (2010). Teoría de las emociones. Estudio histórico-psicológico. España: Akal. 